Article

\title{
Synthesis of Antimicrobial Films Based on Low-Density Polyethylene (LDPE) and Zeolite A Containing Silver
}

\author{
Luís Otávio de Araújo ${ }^{1,2}$, Katya Anaya ${ }^{2}$ (D) and Sibele Berenice Castellã Pergher ${ }^{1, *}$ \\ 1 Molecular Sieves Laboratory (LABPEMOL), Institute of Chemistry, Universidade Federal do Rio Grande do \\ Norte, Av. Senador Salgado Filho, 3000, Lagoa Nova, Campus Universitário, Natal RN 59078-970, Brazil; \\ luisotavio93@yahoo.com.br \\ 2 Laboratory of Food Microbiology, Faculty of Health Sciences of Trairi - FACISA, Universidade Federal do \\ Rio Grande do Norte, R. Teodorico Bezerra, Centro, Santa Cruz RN 59200-000, Brazil; \\ katya_jacinto@yahoo.com.br \\ * Correspondence: sibelepergher@gmail.com; Tel.: +55-84-991-936-083
}

Received: 12 October 2019; Accepted: 16 November 2019; Published: 23 November 2019

\begin{abstract}
The present study aimed at the preparation of antimicrobial films based on low-density polyethylene (LDPE), with zeolite exchanged with Silver (Ag) in 1, 5 and $10 \mathrm{wt} . \%$. Zeolites with Ag were characterized by X-ray diffraction (XRD), scanning electron microscopy (SEM) and X-ray Fluorescence (XRF). LDPE films with added silver-substituted zeolite A were synthesized by wet-casting, with the zeolite content in the films ranging from 1-5 wt.\%. The antibacterial activity of the silver-substituted zeolite was assessed according to its minimum inhibitory concentration (MIC), using Escherischia coli as the target bacteria. LDPE films with silver-loaded zeolite were also tested against E. coli and Staphylococcus aureus. Silver insertion in the zeolite did not change its structure. The MIC of the zeolite with $1 \%$ silver and a concentration of $0.05 \mathrm{mg}$ zeolite/mL was not able to inhibit the visible growth of the bacteria; however, an increased silver concentration resulted in total inhibition after $24 \mathrm{~h}$ of incubation. Zeolites with $5 \%$ and $10 \%$ of silver showed a MIC of $0.05 \mathrm{mg}$ zeolite $/ \mathrm{mL}$. The films with best antibacterial activity against $E$. coli and $S$. aureus were those prepared with 5 wt. \% zeolites loaded with 5\% and 10\% of silver. LDPE films with silver-loaded zeolite A are potential resources in the development of active packaging for food preservation and safety.
\end{abstract}

Keywords: Zeolite A; silver; antimicrobial activity; polymer film

\section{Introduction}

Metals have been widely applied in public health as antimicrobial agents [1], even before the clinical introduction of antibiotics in the 1940s [2]. Silver has been used for decades to inhibit pathogenic microorganisms in a range of areas [3]. Ionic silver has the highest antibacterial activity of all metal ions, and is widely used in topical medicines [4]. In addition to being broad spectrum antimicrobials, silver compounds, when used at appropriate concentrations, exhibit low mammalian cell toxicity [5].

Ionic silver is a Lewis acid with a high affinity to sulfur and nitrogen. Therefore, it can easily affect important biochemical processes. With bacteria, its mechanism of action involves the transformation of DNA into a condensed form, resulting in a significant loss in its replication ability. In addition to damaging genetic material, silver ions react with ribosomes within the cytoplasm, directly affecting the expression of enzymes and proteins essential in the production of important substances for microorganisms [6-8].

Zeolites are among the materials used as carrier supports where silver can be incorporated. They display specific attractive characteristics, such as rigid structures, good thermal, mechanical and 
chemical stability, high specific areas, and microporous systems that allow the controlled release of silver [9]. Zeolite $\mathrm{A}$, modified with $\mathrm{Ag}^{+}$by ion exchange, was reported to exhibit good antibacterial properties against the growth of Escherichia coli and Staphylococcus aureus [3]. The antimicrobial activity of Ag-zeolites on different microorganisms has been previously studied, mainly for application in the health and food fields $[6,10,11]$. Silver can also be incorporated into other materials, such as clays [12,13], ceramics [2] or polymers [14], for specific bioactive applications.

The inclusion of antimicrobial substances in polymeric films inhibits the growth of microorganisms through their gradual release on the surface of the substrate surrounded by these films [15]. There are many studies where the application of antimicrobial agents in polymer films has been tested for pathogen inhibition [16-20]. Reports on the production of polymer films impregnated with Ag-zeolites can also be found in the previous literature $[4,15,21,22]$.

The incorporation of silver-containing zeolites in polymeric matrices has some advantages, including allowing a silver-containing film on both sides, which enhances its antimicrobial effect [23], as well as allowing the gradual release of silver into the medium [24]. These attributes accredit silver-substituted, zeolite-containing films for applications such as active food packaging.

The present study aimed to synthetize and characterize antimicrobial polyethylene films containing silver-exchanged zeolite A, suitable for use as antimicrobial coatings, with a potential application in active food packaging.

\section{Materials and Methods}

\subsection{Materials}

A commercial zeolite A (Diatom, Mexico) was used in the experimental procedures. Zeolite A can also be obtained using IZA (International Zeolite Association) methodology synthesis [25]. The model microorganisms tested in the study of antimicrobial activity were strains of Escherichia coli (ATTC 25922) and Staphylococcus aureus (ATTC 25923). Lactose broth (BD, Atlanta, United States) was used to determine the minimum inhibitory concentration. Mueller-Hinton agar (TM Media, Dehli, India) was used for the plate diffusion method. Commercial low-density polyethylene $\left(\left(-\mathrm{CH}_{2}-\mathrm{CH}_{2}-\right)_{\mathrm{n}}\right.$ Branched $)$ (LDPE) (BRASKEM, Porto Alegre, Brazil), in pellet form, was used as a base polymer for the preparation of the films. For wet-casting film preparation, xylol $\left(\mathrm{C}_{8} \mathrm{H}_{10}\right)$ (Êxodo Científica, São Paulo, Brazil) was used for LDPE solubilization. The silver ions were obtained using $99 \%$ silver nitrate $\left(\mathrm{AgNO}_{3}\right)$ (Êxodo Científica, São Paulo, Brazil).

\subsection{Silver Incorporation in Zeolite A}

Silver was incorporated into zeolite A by cationic exchange. In a beaker protected from light, $3 \mathrm{~g}$ of the zeolitic material and $50 \mathrm{~mL}$ of $1 \%, 5 \%$ or $10 \% \mathrm{AgNO}_{3}$ solution $(w / v)$ were added. The system was kept under magnetic stirring at room temperature for $2 \mathrm{~h}$. After the exchange, the material was filtered and placed in a drying oven at $60^{\circ} \mathrm{C}$ overnight. The solids were stored in suitable containers in a dry place, protected from light.

\subsection{Calculation of Crystallinity of Zeolite A}

The crystallinity of zeolite A, substituted with different silver concentrations, was calculated by comparing the intensity of the following $2 \theta$ reflections: $7.2^{\circ} ; 12.5^{\circ} ; 16.1^{\circ} ; 21.7^{\circ} ; 30^{\circ} ; 34.2^{\circ}$. Commercial zeolite $\mathrm{A}$, with no insertion of $\mathrm{Ag}$, was used as a standard.

\subsection{Preparation of Composite Films}

The films were produced using xylol solubilization. On solubilization, $5 \mathrm{~g}$ of LDPE was dissolved in $45 \mathrm{~mL}$ xylol at $120^{\circ} \mathrm{C}$, at reflux, for $1 \mathrm{~h}$. After completing the polymer solubilization, the material was transferred to a petri dish under a constant heat of $110^{\circ} \mathrm{C}$ for film formation. Following the same 
polymer solubilization procedure, $1 \%, 2.5 \%$ and $5 \%(w / w)$ of each silver-substituted zeolite $(1 \%, 5 \%$ or $10 \% \mathrm{ag}$ ) was incorporated to form the composite film.

\subsection{Characterization of Materials}

The characterization of silver-exchanged zeolite A was carried out using X-ray diffraction spectroscopy (XRD, D2 Phaser, Bruker, with Lynxeye detector, Atibaia, Brazil), field emission scanning electron microscopy (FESEM, Auriga, Zeiss, Madrid, Espanha), and X-ray Fluorescence spectroscopy (XRF, S2 Ranger, Bruker, Atibaia, Brazil).

\subsection{Antimicrobial Activity of Silver Exchanged Zeolite A}

The antimicrobial analysis of the Ag-zeolite was carried out using the minimum inhibitory concentration (MIC) technique, using E. coli (ATCC 25922) and S. aureus (ATCC 25923). The MIC was determined through broth macro-dilution [26,27]. Ten different concentrations of zeolite A, containing $1 \%, 5 \%$ and $10 \%$ silver, were tested. The concentration ranged from $0.05 \mathrm{mg} / \mathrm{mL}$ to $25.6 \mathrm{mg} / \mathrm{mL}$. The broth macro-dilution method involves arranging broth-containing tubes with varying contents of the compound with antimicrobial activity. Aliquots of the microorganism to be tested are then added to the tubes containing the antimicrobial compound. The selected microorganism was cultivated in a lactose broth at $35^{\circ} \mathrm{C}$ for $24 \mathrm{~h}$. The adjustment of the bacterial inoculum was based on the $0.5 \mathrm{McF}$ arland scale. To obtain the MIC, $1 \mathrm{~mL}$ of the bacterial inoculum was inserted into tubes containing $1 \mathrm{~mL}$ of the antimicrobial compound. The tubes were incubated at $35^{\circ} \mathrm{C}$ for $24 \mathrm{~h}$ and after this period, the turbidity was visually read.

\subsection{Antimicrobial Activity of Composite Films}

The antimicrobial activity of the polymer films was determined using the plate diffusion method [27]. The bacterial inoculum tested were previously adjusted using a spectrophotometer to correspond to 0.5 on the McFarland scale. The microbial culture was spread over a Petri dish containing Mueller-Hinton agar. The polymer films were cut into discs, each $4 \mathrm{~mm}$ in diameter. In each plate, four discs, corresponding to the blank (pure polymer) and three Ag-zeolite mass concentrations, were placed on the inoculated agar and incubated at $35^{\circ} \mathrm{C}$ for $24 \mathrm{~h}$. Inhibition was verified using a manual paquimeter. The halos were measured, taking into account the diameter of the disc, plus the area of the opaque zone (halo). All the tests were performed in triplicate.

\section{Results and Discussion}

\subsection{Materials Characterization}

X-ray diffractograms for 1\%, 5\% and 10\% silver-substituted zeolite A are shown in Figure 1. The characteristic reflections of zeolite A were observed at $2 \theta$ values of $7.2^{\circ}, 12.5^{\circ}, 16.1^{\circ}, 21.7^{\circ}, 30^{\circ}$ and $34.2^{\circ}$. Therefore, the cation exchange process does not cause structural changes in the zeolitic material, or in the emergence of other phases, as was previously reported [28]. However, in the commercial zeolite sample there were impurities, as denoted by the $2 \theta$ peak of $9.0^{\circ}$. In addition, there was a clear decrease in peak intensity when an increasing silver content was incorporated into the zeolite. This pattern has been explained in the literature as a result of the incorporation of silver and other cations in zeolites, and may be due, among other reasons, to the internal redistribution of cationic charge in the material and the loss of crystallinity $[15,29]$. Besides this, the amount, position and nature of the extra-network cations from the cation exchange process also explain the variations in peak intensity observed in the diffractograms [10]. Rivera-Garza et al. found that the impregnation of clinoptilonite zeolite with sodium or silver at low concentrations did not lead to significant changes in diffraction patterns [30]. Zhou et al. incorporated $365.73 \mathrm{mg} / \mathrm{g}$ of silver in zeolite $\mathrm{A}$, and did not observe structural changes in X-ray diffractograms, evidencing an excellent cationic exchange process [31]. 


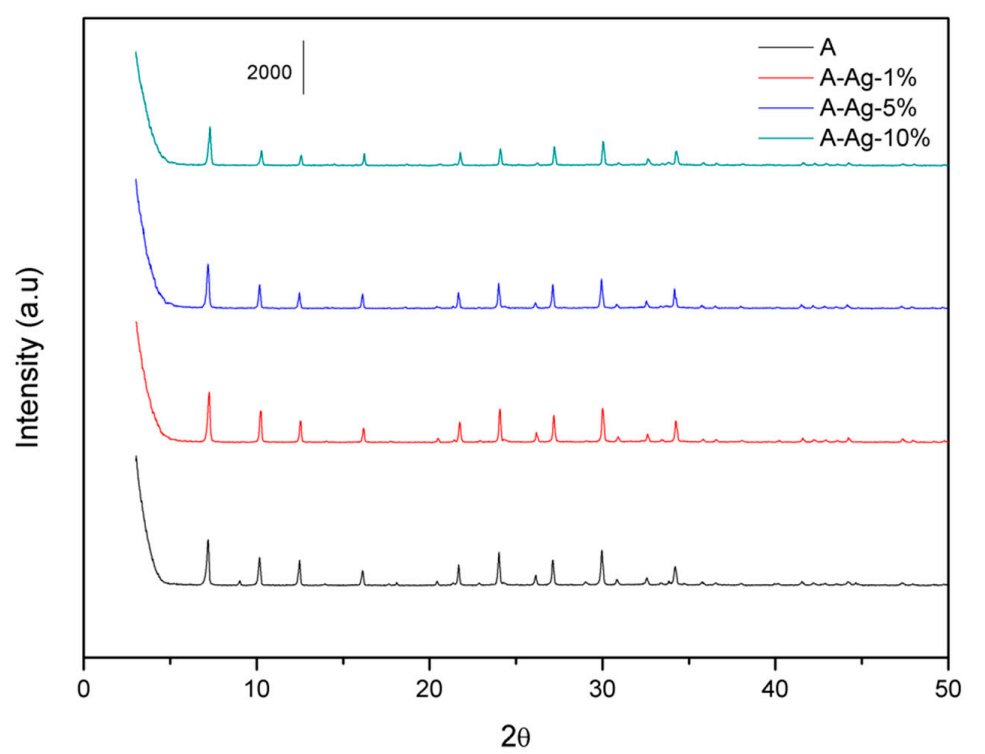

Figure 1. X-ray diffraction (XRD) of zeolite A without Ag (red line), $1 \% \mathrm{Ag}$ (Blue line), $5 \% \mathrm{Ag}$ (yellow line) and $10 \% \mathrm{Ag}$ (green line).

According to Table 1, a sharp decrease in the crystallinity of silver-substituted materials is observed, mainly at $5 \%$ and $10 \%$, which corroborates the results obtained using the X-ray diffractograms. The silver contents obtained by XRF analysis (Table 1) were found to increase with the nominal synthesis content, as expected, and were relatively close for samples containing $1 \%$ and $10 \%$ silver.

Table 1. Crystallinity values (\%) and Elemental Chemical Composition (\% by mass) for the silver-substituted materials.

\begin{tabular}{ccc}
\hline Sample & Crystallinity (\%) & Ag (XRF) (\%) \\
\hline Zeolite A & 100 & 0 \\
Zeolite A-Ag (1\%) & 98 & 0.79 \\
Zeolite A-Ag (5\%) & 86 & 1.57 \\
Zeolite A-Ag (10\%) & 70 & 13.29 \\
\hline
\end{tabular}

Considering that zeolites are porous materials, it can be inferred that small contents, such as $1 \%$ silver, should be close to the surface, so the nominal values agree with those measured by the technique. When the amount is increased to $5 \%$, the incorporation tends to be more intense and, therefore, only $1.57 \%$ is measured, as most of the silver is within the zeolitic material structure. With a higher content of silver $(10 \%)$, the entire interior of the zeolite has already been filled and the outside is probably covered, or partially covered, with silver. Also, based on XRF results, it was observed that the Si/Al ratio of the materials remained constant and close to 1 , indicating that the incorporation of silver does not significantly change the chemical composition of the zeolite surface.

Figure 2 presents the SEM images for the materials under study. The material shows the typical cubic morphology of zeolite A; however, the presence of an amorphous material (possibly sodalite) is also observed. Another important feature is the crystal intergrowth, denoted by the interpenetrated growth of some cubes over others, indicating that the synthesis, although resulting in zeolite A, does not achieve the same degree of purity as a small-scale one. This suggests that the material is commercial zeolite A, obtained using large-scale synthesis, which, in principle, does not influence the material performance. The maintenance of cubic morphology demonstrates that the cation exchange process does not cause structural changes in the material, regardless of the amount of silver added, which is in agreement with the literature $[3,10]$. 

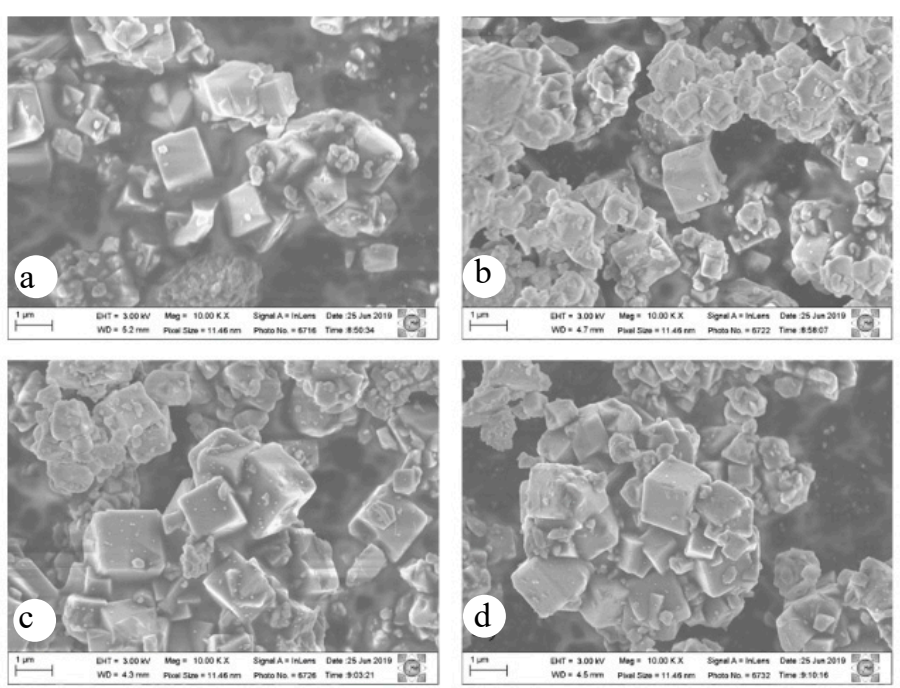

Figure 2. Scanning electron microscopy (SEM) images of the (a) Zeolite A, (b) Zeolite A-Ag-1\%, (c) Zeolite A-Ag-5\% and (d) Zeolite A-Ag-10\%.

\subsection{Minimum Inhibitory Concentration of Zeolite Impregnated with Different Silver Contents}

Minimum inhibitory concentration is defined as the lowest concentration of an antimicrobial agent that prevents the visible growth of a microorganism in the agar or broth dilution susceptibility tests [32]. In the present analysis, the target microorganism tested was E. coli.

The results were interpreted according to the turbidity of the medium, which was proportionally related to microbial growth. The zeolite A with a silver content $1 \%$, at a concentration of $0.05 \mathrm{mg}$ zeolite/mL (Figure 3b), was unable to inhibit the visible growth of $E$. coli. However, with an increase in concentration, there was total inhibition after the $24 \mathrm{~h}$ incubation period. Thus, for the zeolite A-Ag- $1 \%$, the MIC was $0.1 \mathrm{mg} / \mathrm{mL}$ (Figure 3c).
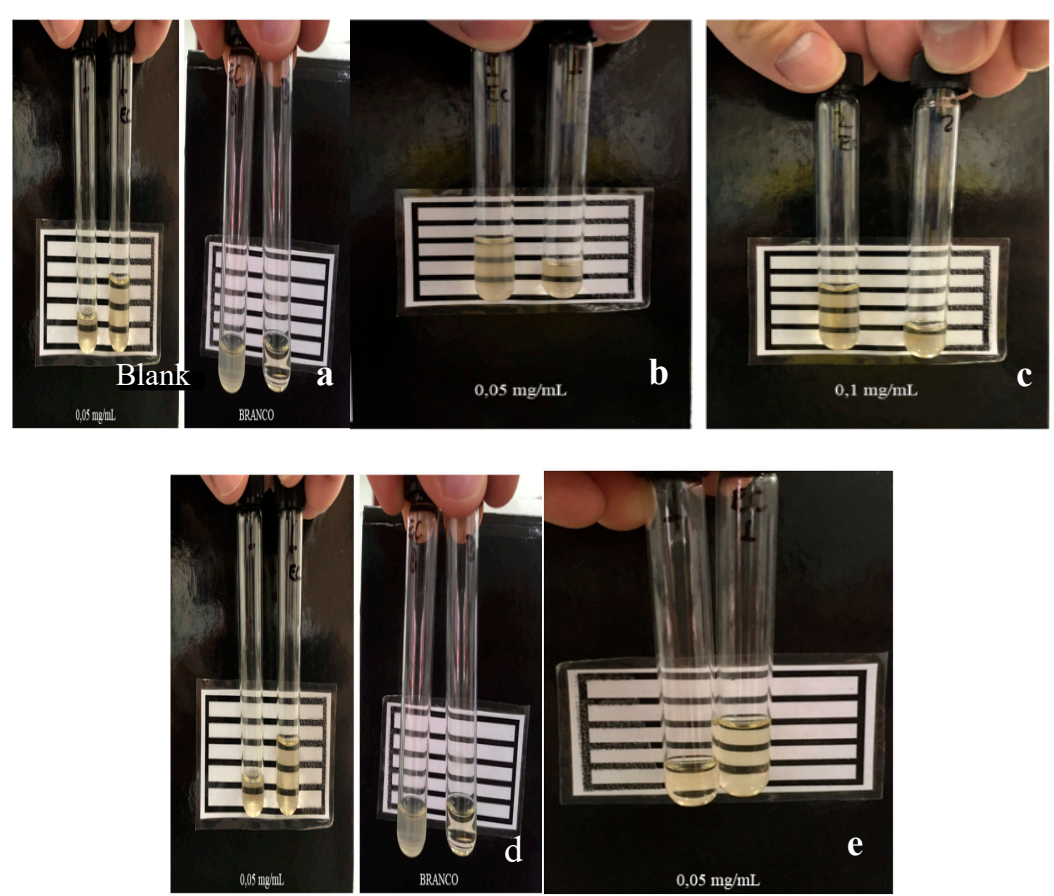

Figure 3. Minimum inhibitory concentration of silver-exchanged zeolite A with (a) $0 \%$ silver; (b) and (c) $1 \%$ silver; (d) $5 \%$ silver; (e) $10 \%$ silver. 
The incorporation of $5 \%$ silver into zeolite A resulted in an MIC not greater than $0.05 \mathrm{mg} / \mathrm{mL}$, as shown in Figure 3d. Similarly, 10\% silver-substituted zeolite A also inhibited microbial growth at the minimum concentration tested (Figure 3e).

Jiraroj et al. tested zeolite A and silver composites, with varying silver concentrations from 25 to $200 \mathrm{mg} / \mathrm{mL}$, and fixed the composite concentration to $0.1 \mathrm{mg}$ zeolite $/ \mathrm{mL}$. The inhibition effect was accentuated against E. coli bacteria. There was an $80 \%$ to $90 \%$ inhibition in silver concentrations between 50 and $200 \mathrm{mg} / \mathrm{L}$ [3]. Krishnani et al. [33], working with zeolite A and silver, found a MIC of $40 \mu \mathrm{g} / \mathrm{mL}$ when testing in E. coli, resulting in similar findings to those reported in the present study. Tosheva et al. used zeolite $\mathrm{X}$ and beta zeolite, both containing silver at concentrations ranging from 0.05 to $0.5 \mathrm{mg}$ zeolite $/ \mathrm{mL}$. The MIC of zeolite $\mathrm{X}$ was $0.1 \mathrm{mg} / \mathrm{mL}$ for the inhibition of E. coli. Beta zeolite was effective from 0.05 to $0.5 \mathrm{mg} / \mathrm{mL}$ [9]. Other authors reported the loading of $5.8 \%(\mathrm{w} / \mathrm{w})$ silver in zeolite $X$, finding the excellent inhibition of Gram-negative and Gram-positive microorganisms over the course of $24 \mathrm{~h}$, with no growth occurring within the first hour of analysis [34].

The effectiveness of silver-exchanged zeolite as an antibacterial compound can be attributed to the high amount of silver ions and, possibly, the low reduction of $\mathrm{Ag}^{+}$in elemental silver on the zeolite surface [33].

\subsection{Antimicrobial Activity of the Polymer Containing Zeolite Impregnated with Silver}

After identifying the remarkable antimicrobial activity of zeolite A with different silver concentrations, antimicrobial activity was tested using the plate diffusion method with the LDPE composite films, loaded with different concentrations of silver-exchanged zeolite A.

There was no microbial growth inhibition for films containing $1 \%$ silver in all mass ratios (Figure $4 a, b$ ), nor for films containing $1 \%$ and $2.5 \%$ by mass at $5 \%$ silver concentration. For the $10 \%$ silver films, there was no inhibition when the mass ratio was $1 \%$. However, discs containing zeolite in the ratios $2.5 \%(w / w)$ and $5 \%(w / w)$, with silver concentrations of $5 \%$ and $10 \%$, were more effective against both microorganisms tested (Figure 4c-f). The inhibition halos reached 5-6 $\mathrm{mm}$ in diameter. They are highlighted in Figure 4c1,d1,e1,e2,f1.

Boschetto et al. [15], working with $7 \mathrm{~mm}$ diameter discs composed of LDPE and silver-substituted zeolite $\mathrm{Y}$, obtained inhibition halos close to $7 \mathrm{~mm}$ using E. coli as a target bacteria. Sánchez et al. [35], using discs with silver-substituted zeolite ZSM-5, obtained inhibition halos that were $1 \mathrm{~cm}$ in diameter when testing for the inhibition of E. coli. In comparison with other studies, the inhibition halos observed in this study were smaller. However, according to SNV 195920-1992, the presence of an inhibition zone greater than $1 \mathrm{~mm}$ is considered to be an indication of good inhibition, and the presence of a zone smaller than $1 \mathrm{~mm}$ is considered reasonably good [36].

No microbial growth inhibition was visualized in the LDPE films without zeolite A containing silver (discs identified as "blank" in the Figure 4). Therefore, it is evident that the inhibition of microorganisms is, in fact, related to the release of silver by the film. Plates containing agar do not present considerable amounts of water, which hinders the diffusion of the active agent in the medium and, consequently, generates smaller inhibition halos [15]. 

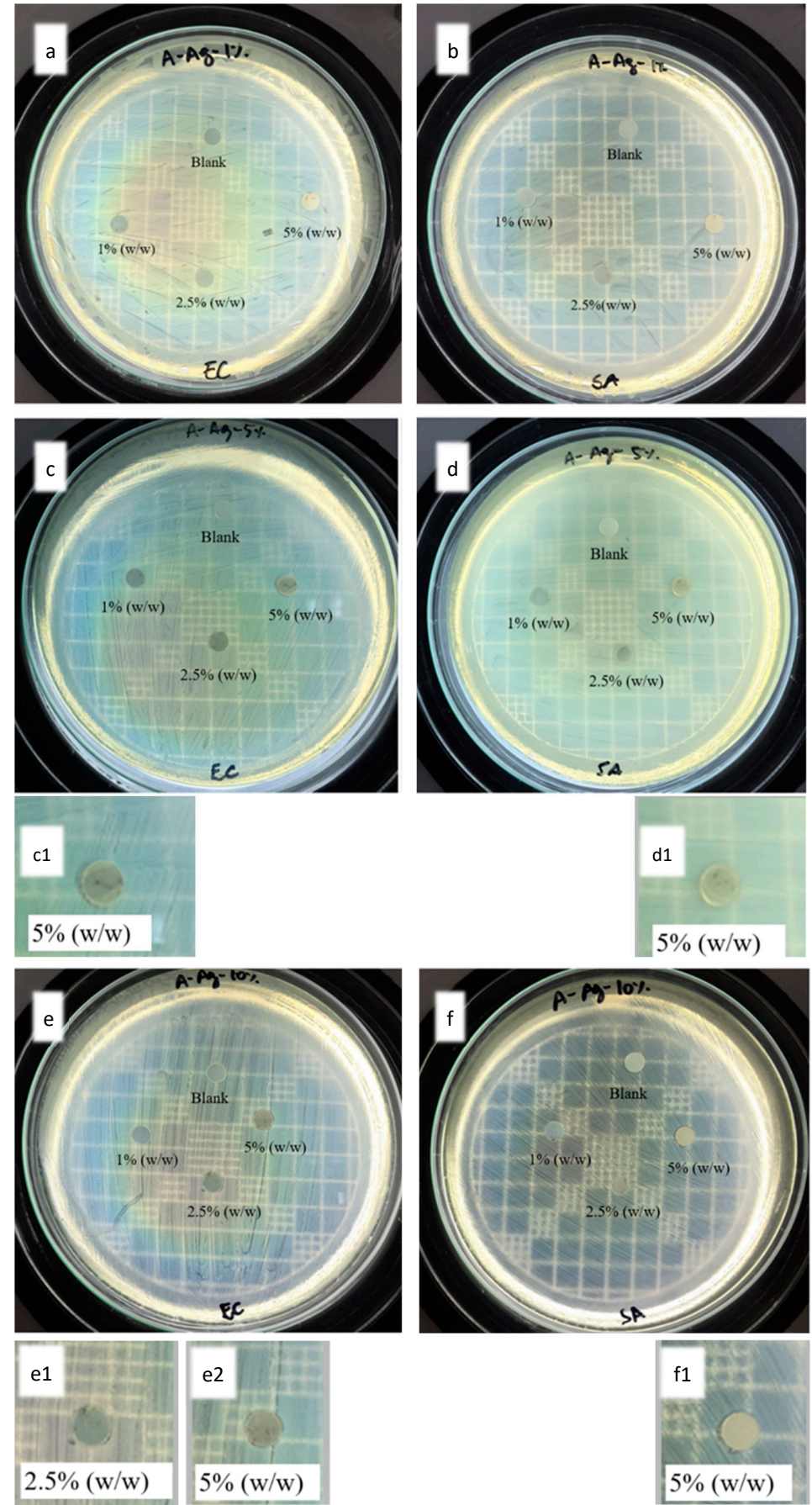

Figure 4. Antimicrobial activity of LDPE films with different concentrations ( $1 \%, 2.5 \%$ and $5 \% \mathrm{w}: \mathrm{w})$ of zeolite A loaded with Ag. (a) Films with zeolite A-Ag-1\% against E. coli. (b) Films with zeolite A-Ag- $1 \%$ against $S$. aureus. (c) Films with zeolite A-Ag-5\% against E. coli. (c1) Inhibition halo produced by the film with $5 \%$ of zeolite A-Ag-5\% against E. coli. (d) Films with zeolite A-Ag-5\% against S. aureus. (d1) Inhibition halo produced by the film with $5 \%$ of zeolite A-Ag-5\% against S. aureus. (e) Films with zeolite A-Ag- $10 \%$ against E. coli. (e1) Inhibition halo produced by the film with $2.5 \%$ of zeolite A-Ag-10\% against E. coli. (e2) Inhibition halo produced by the film with $5 \%$ of zeolite A-Ag- $10 \%$ against E. coli. (f) Films with zeolite A-Ag-10\% against S. aureus. (f1) Inhibition halo produced by the film with $5 \%$ of zeolite $\mathrm{A}-\mathrm{Ag}-5 \%$ against $\mathrm{S}$. aureus. 


\section{Conclusions}

The incorporation of different silver concentrations in zeolite A did not morphologically alter the material under study. However, with increasing silver content, there was a decrease in reflections on $\mathrm{XRD}$ analysis, probably due to the loss of crystallinity after cation exchange.

An important antimicrobial activity was performed by zeolites A containing 5\% and 10\% silver, and when they were incorporated into LDPE films at concentrations of $2.5 \%$ and $5 \%$, respectively, they were able to inhibit bacterial growth at a satisfactory rate. Therefore, those composite films demonstrated the potential for diverse applications, such as in the development of active packaging for food or pharmaceutical products. Given the intended purpose, additional studies must be carried out, not only for a better characterization of the material, but also, regarding silver diffusivity, aiming toward the prolonged antimicrobial effect of the films.

Author Contributions: Conceptualization, S.B.C.P., L.O.d.A. and K.A.; methodology, S.B.C.P., L.O.D.A. and K.A.; formal analysis, S.B.C.P., L.O.D.A. and K.A.; investigation, L.O.D.A. and K.A.; resources, S.B.C.P. and L.O.D.A.; data curation, S.B.C.P. and K.A.; writing-original draft preparation, S.B.C.P., L.O.D.A. and K.A.; writing-review and editing, S.B.C.P. and K.A.; supervision, S.B.C.P. and K.A.; project administration, S.B.C.P. and K.A.; funding acquisition, S.B.C.P. and K.A.

Funding: This research was funded by Universidade Federal do Rio Grande do Norte-UFRN.

Conflicts of Interest: The authors declare no conflict of interest.

\section{References}

1. Vincent, M.; Hartemann, P.; Engels-Deutsch, M. Antimicrobial applications of copper. Int. J. Hyg. Environ. Health 2016, 219, 585-591. [CrossRef] [PubMed]

2. Osés, J.; Fuentes, G.G.; Palacio, J.F.; Esparza, J.; García, J.A.; Rodríguez, R. Antibacterial Functionalization of PVD Coatings on Ceramics. Coatings 2018, 8, 197. [CrossRef]

3. Jiraroj, D.; Tungasmita, S.; Tungasmita, D.N. Silver ions and silver nanoparticles in zeolite a composites for antibacterial activity. Powder Technol. 2014, 264, 418-422. [CrossRef]

4. Pehlivan, H.; Balkose, D.; Ulku, S.; Tihminlioglu, F. Characterization of pure and silver exchanged natural zeolite filled polypropylene composite films. Compos. Sci. Technol. 2005, 65, 2049-2058. [CrossRef]

5. Zhao, G.; Stevens, S.E. Multiple parameters for the comprehensive evaluation of the susceptibility of Escherichia coli to the silver ion. BioMetals 1998, 11, 27-32. [CrossRef]

6. Chernousova, S.; Epple, M. Silver as Antibacterial Agent: Ion, Nanoparticle, and Metal. Angew. Chem. Int. Ed. 2013, 52, 1636-1653. [CrossRef]

7. Feng, Q.L.; Wu, J.; Chen, G.Q.; Cui, F.Z.; Kim, T.N.; Kim, J.O. A mechanistic study of the antibacterial effect of silver ions on Escherichia coli and Staphylococcus aureus. J. Biomed. Mater. Res. 2000, 52, 662-668. [CrossRef]

8. Yamanaka, M.; Hara, K.; Kudo, J. Bactericidal Actions of a Silver Ion Solution on Escherichia coli, Studied by Energy-Filtering Transmission Electron Microscopy and Proteomic Analysis. Appl. Environ. Microbiol. 2005, 71, 7589-7593. [CrossRef]

9. Tosheva, L.; Belkhair, S.; Gackowski, M.; Malic, S.; Al-Shanti, N.; Verran, J. Rapid screening of the antimicrobial efficacy of Ag zeolites. Colloids Surf. B 2017, 157, 254-260. [CrossRef]

10. Cerrillo, J.L.; Palomares, A.E.; Rey, F.; Valencia, S.; Palou, L.; Pérez-Gago, M.B. Ag-zeolites as fungicidal material: Controlo f citrus green mold caused by Penicillium digitatum. Microporous Mesoporous Mater. 2017, 254, 69-76. [CrossRef]

11. Ferreira, L.; Fonseca, A.M.; Botelho, G.; Almeida-Aguiar, C.; Neves, I.C. Antimicrobial activity of faujasite zeolites doped with silver. Microporous Mesoporous Mater. 2012, 160, 126-132. [CrossRef]

12. Roy, A.; Butola, B.S.; Joshi, M. Synthesis, characterization and antibacterial properties of novel nano-silver loaded acid activated montmorillonite. Appl. Clay Sci. 2017, 146, 278-285. [CrossRef]

13. Malachová, K.; Praus, P.; Rybková, Z.; Kozák, O. Antibacterial and antifungal activities of silver, copper and zinc montmorillonites. Appl. Clay Sci. 2011, 53, 642-645. [CrossRef] 
14. Cruz-Pacheco, A.F.; Muñoz-Castiblanco, D.T.; Cuaspud, J.A.G.; Paredes-Madrid, L.; Vargas, C.A.P.; Zambrano, J.J.M.; Gómez, C.A.P. Coating of Polyetheretherketone Films with Silver Nanoparticles by a Simple Chemical Reduction Method and Their Antibacterial Activity. Coatings 2019, 9, 91. [CrossRef]

15. Boschetto, D.L.; Lerin, L.; Cansian, R.; Pergher, S.B.C.; Di Luccio, M. Preparation and antimicrobial activity of polyethylene composite films with silver exchanged zeolite-Y. Chem. Eng. J. 2012, 204, 210-216. [CrossRef]

16. Ribeiro-Santos, R.; Sanches-Silva, A.; Motta, J.F.G.; Andrade, M.; Neves, I.A.; Teófilo, R.F.; Carvalho, M.G.; Melo, N.R. Combined use of essential oils applied to protein base active food packaging: Study in vitro and in a food simulant. Eur. Polym. J. 2017, 93, 75-86. [CrossRef]

17. Suppakul, P.; Miltz, J.; Sonneveld, K.; Bigger, S.W. Efficacy of polyethylene-based antimicrobial films containing principal constituents of basil. LWT-Food Sci. Technol. 2008, 41, 779-788. [CrossRef]

18. Oussalah, M.; Caillet, S.; Salmiéri, S.; Saucier, L.; Lacroix, M. Antimicrobial and Antioxidant Effects of Milk Protein-Based Film Containing Essential Oils for the Preservation of Whole Beef Muscle. J. Agric. Food Chem. 2004, 52, 5598-5605. [CrossRef]

19. Mecitoglu, Ç.; Yemenicioglu, A.; Arslanoglu, A.; Elmaci, Z.S.; Korel, F.; Çetin, A.E. Incorporation of partially purified hen egg whitelysozyme into zein films for antimicrobial food packaging. Food Res. Int. 2006, 39, 12-21. [CrossRef]

20. Marcos, B.; Aymerich, T.; Monfort, J.M.; Garriga, M. High-pressure processing and antimicrobial biodegradable packaging to control Listeria monocytogenes during storage of cooked ham. Food Microbiol. 2008, 25, 177-182. [CrossRef]

21. Kamisoglu, K.; Aksoy, E.A.; Akata, B.; Hasirci, N.; Baç, N. Preparation and Characterization of Antibacterial Zeolite-Polyurethane Composites. J. Appl. Polym. Sci. 2008, 110, 2854-2861. [CrossRef]

22. Fernández, A.; Soriano, E.; Hernández-Muñoz, P.; Gavara, R. Migration of antimicrobial silver from composites of polylactide with silver zeolites. J. Food Sci. 2010, 75, 186-193. [CrossRef] [PubMed]

23. Zampino, D.; Ferreri, T.; Puglisi, C.; Mancuso, M.; Zaccone, R.; Scaffaro, R.; Bennardo, D. PVC silver zeolite composites with antimicrobial properties. J. Mater. Sci. 2011, 46, 6734-6743. [CrossRef]

24. Muñoz-Bonilla, A.; Fernández-García, M. Polymeric materials with antimicrobial activity. Prog. Polym. Sci. 2012, 37, 281-339. [CrossRef]

25. International Zeolite Association. 2019. Available online: http://iza-online.org/synthesis/default.htm (accessed on 9 November 2019).

26. Balouiri, M.; Sadiki, M.; Ibnsouda, S.K. Methods for in vitro evaluating antimicrobial activity: A review. J. Pharm. Anal. 2016, 6, 71-79. [CrossRef] [PubMed]

27. NCCLS. Performance Standards for Antimicrobial Disk Susceptibility Tests; National Committee for Clinical Laboratory Standards: Wayne, PA, USA, 2003.

28. Fonseca, A.M.; Neves, I.C. Study of silver species stabilized in different microporous zeolites. Microporous Mesoporous Mater. 2013, 181, 83-87. [CrossRef]

29. Salavati-Niasari, M. Synthesis and characterization of 18-and 20-membered hexaazamacrocycles containing pyridine manganese (II) complex nanoparticles dispersed within nanoreactors of zeolite-Y. Polyhedron 2009, 28, 2321-2328. [CrossRef]

30. Rivera-Garza, M.; Olguín, M.T.; García-Sosa, I.; Alcántara, D.; Rodríguez-Fuentes, G. Silver supported on natural Mexican zeolite as an antibacterial material. Microporous Mesoporous Mater. 2000, 39, 431-444. [CrossRef]

31. Zhou, Y.; Deng, Y.; He, P.; Dong, F.; Xia, Y.; He, Y. Antibacterial zeolite with a high silver-loading content and excellent antibacterial performance. RSC Adv. 2014, 4, 5283-5288. [CrossRef]

32. Andrews, J.M. Determination of minimum inhibitory concentrations. J. Antimicrob. Chemother. 2001, 48, 5-16. [CrossRef]

33. Krishnani, K.K.; Zhang, Y.; Xiong, L.; Yan, Y.; Boopathy, R.; Mulchandani, A. Bactericidal and ammonia removal activity of silver ion-exchanged zeolite. Bioresour. Technol. 2012, 117, 86-91. [CrossRef] [PubMed]

34. Kwakye-Awuah, B.; Williams, C.; Kenward, M.A.; Radecka, I. Antimicrobial action and efficiency of silver-loaded zeolite X. J. Appl. Microbiol. 2007, 104, 1516-1524. [CrossRef] [PubMed] 
35. Sánchez, M.J.; Mauricio, J.E.; Paredes, A.R.; Gamero, P.; Cortés, D. Antimicrobial properties of ZSM-5 type zeolite functionalized with silver. Mater. Lett. 2017, 191, 65-68. [CrossRef]

36. Pollini, M.; Paladini, F.; Catalano, M.; Taurino, A.; Licciulli, A.; Maffezolli, A.; Sannino, A. Antibacterial coatings on haemodialysis catheters by photochemical deposition of silver nanoparticles. J. Mater. Sci. 2011, 22, 2005-2012. [CrossRef] [PubMed]

(C) 2019 by the authors. Licensee MDPI, Basel, Switzerland. This article is an open access article distributed under the terms and conditions of the Creative Commons Attribution (CC BY) license (http://creativecommons.org/licenses/by/4.0/). 